\title{
Assessment of Fruit Fly Trapping System in Mango Orchards in Northern Côte d'Ivoire
}

\author{
Magloire Yves Minhibo ${ }^{1}$, Ossey Robert Ndepo ${ }^{2}$, N'Klo Hala ${ }^{3}$, Hervé Koua ${ }^{4}$, Yalamoussa Tuo ${ }^{5}$, Aby N'Goran ${ }^{1}$, \\ Adama Coulibaly ${ }^{1}$, Sékou Doumbia ${ }^{1}$, Jean-Baptiste Akadié Djaha ${ }^{1}$, Charles Konan Kouakou ${ }^{1}$, Achille Nda \\ Adopo ${ }^{1}$, Hugues Anicet $\mathrm{Nda}^{1}$ and Hortense Djidji ${ }^{1}$ \\ 1. National Center for Agronomic Research, Station of Korhogo-Lataha, Korhogo BP 856, Côte d'Ivoire \\ 2. Jean Lorougnon Guédé University (UJLG), Daloa BP 150, Côte d'Ivoire \\ 3. National Center for Agronomic Research, Station of La Mé, Abidjan 13 BP 989, Côte d'Ivoire \\ 4. University Felix Houphouet Boigny (UFHB), Abidjan 22 BP 582, Côte d'Ivoire \\ 5. University Peleforo Gon Coulibaly (UPGC), Korhogo BP 1328, Côte d'Ivoire
}

\begin{abstract}
Mango is the third largest export fruit in Côte d'Ivoire. However, its yield is limited by the damage caused by fruit flies (Diptera: Tephritidae). This study aimed at assessing the trapping system for fruit fly detection and monitoring in mango orchards in Northern Côte d'Ivoire. Four sites were selected in Northern Côte d'Ivoire in mango production area and in timber yard areas. Five trapping systems were tested: two food attractants (torula yeast, CeraTrap) and three sex attractants (methyl eugenol, trimedlure, cue-lure). Plastic bottles were used for food attractants and commercial traps for sex attractants. Five traps per treatment with three repetitions per site were set up. Ten species of flies have been identified: Bactrocera dorsalis, B. cucurbitae, Ceratitis anonae, C. bremii, C. capitata, C. cosyra, C. punctata, Dacus ciliatus, D. punctatifrons and Dacus spp.. Among these species, B. dorsalis was dominant. It was captured by $94.04 \%$ and $90.94 \%$, respectively, in mango orchards and forest areas included wild fruits. The average number of individuals captured varied from one species to another, depending on the attractants. This average was estimated to 379.91, 27.58, 25.55, 15.1 and 11.93, respectively, for méthyl eugénol, torula yeast, CeraTrap, cue-lure, trimedlure. The attractants have shown their specificity in capturing fly species. Methyl eugenol had the highest capture and was the most effective.
\end{abstract}

Key words: Fruit flies, attractant, traps, monitoring, mangoes.

\section{Introduction}

Fruit cultivation occupies an important place in the agricultural policy of Côte d'Ivoire. Indeed, fruits play a predominant economic and social role by meeting the needs of populations [1]. In Côte d'Ivoire, mango (Mangifera indica L.), mostly grown in the north of the country, is the third cash crop after cotton (Gossypium hirsutum L.) and cashew (Anacardium occidentale L.) [2]. This crop is a fundamental source of nutrition in the Sudano-Sahelian region of West Africa and provides employment and foreign exchange [3]. West Africa is one of the mango

Corresponding author: Magloire Yves Minhibo, Ph.D., research fields: entomology and crop protection. producing regions. Mango plays a major role in local, national, regional and international markets [4]. Unfortunately, fruits and vegetables are continually threatened by pests. Among the pests, fruit flies are by far the most significant ones. They are considered to be one of the most dangerous crop pests in the world according to De Meyer [5]. More than 4,000 species of this family are known throughout the world with a wide distribution covering tropical and subtropical zones, as well as temperate zones, and occupying diverse habitats ranging from rainforests to dry savannahs [6]. Fruit fly larvae causes decay in plant tissues after oviposition stings of pregnant females. Various plant species are attacked by fruit flies, namely: (i) fruit (citrus fruits, apples, mangoes, etc.); 
(ii) vegetable (watermelons, squashes, tomatoes, etc.);

(iii) adventitious. The damage attributed to these formidable predators each year is estimated at more than $80 \%$, or even $100 \%$, in mango producing areas when no control method is applied [2, 7]. These quarantine insects restrict the development of horticultural crops in many tropical countries and are a limiting factor in the export of fruits and vegetables for some countries. In West Africa and Côte d'Ivoire, in particular, mangoes are heavily attacked by an exotic, highly invasive species oriental fruit fly Batrocera dorsalis [2, 8]. This has resulted in a fall in the national yield of mangoes and the decline of the country as a global supplier to the European market. Today, Côte d'Ivoire is in the third place after Brazil and Peru [9], because the quantity of mangoes from Brazil and Peru exported to the European market is greater than that of Côte d'Ivoire. These fruit predators are of concern because of the direct damage (stings) caused to mangoes and therefore a threat to the mango industry. Unfortunately, chemical control is not effective in stopping the damage caused by flies [3], because fruit flies have a complex biology and chemical control has adverse effects on the environment, producers and consumers. Thus, an integrated management approach combining bait attractiveness and trapping system effectiveness was implemented for the sustainable control of fruit flies. This study aimed at assessing the effectiveness of the different attractants (sexuels, food) and trapping systems for fruit fly detection and monitoring.

\section{Materials and Methods}

\subsection{Location of Study Sites}

This study was conducted from May 2015 to June 2016 in two localities: Korhogo and Ferkessédougou. These localities belong to the Sudanian climate zone, characterized by a rainy season of 5-6 months, with rainfall of 1,150-1,350 mm/year and a humidity of $40 \%-50 \%$. The vegetation of this zone is a wooded savannah with woodlands and gallery forests along streams. These localities were chosen because the host plants of fruit flies are found there. Indeed, Korhogo and Ferkessédougou are two large mango producing zones in Côte d'Ivoire. Two study sites were selected in each locality according to the following criteria: presence of fruit fly host plants (mango trees and other fruit species) and accessibility. For the locality of Korhogo, the selected sites were: the research station of Lataha $\left(9^{\circ} 34^{\prime} \mathrm{N}\right.$ and $\left.5^{\circ} 37^{\prime} \mathrm{W}\right)$, where mango orchards and other fruit species are planted; the research station of Kamonon Diabaté, private structure $\left(9^{\circ} 33^{\prime} \mathrm{N}\right.$ and $\left.5^{\circ} 40^{\prime} \mathrm{W}\right)$, containing wood, African locust and shea tree productions, making up a small natural forest of about 40 ha. For the locality of Ferkessédougou, fly capturing was carried out on the research station of the National Center for Agronomic Research $\left(9^{\circ} 36^{\prime} \mathrm{N}\right.$ and $\left.5^{\circ} 12^{\prime} \mathrm{W}\right)$, and the forest relic of Petit Clerc, whose geographical coordinates are $5^{\circ} 55^{\prime}$ $\mathrm{N}$ and $3^{\circ} 30^{\prime} \mathrm{N}$ and $10^{\circ} 30^{\prime} \mathrm{W}$ and $8^{\circ} 35^{\prime} \mathrm{W}$. The climate is Sudanese with two long seasons: a long dry season (duration seven months) and a long rainy season (duration five months). The average annual rainfall is $1,300 \mathrm{~mm}$. The average temperatures recorded ranged from $22{ }^{\circ} \mathrm{C}$ to $28{ }^{\circ} \mathrm{C}$. The vegetation is mainly composed of wooded and grassy savannahs, and there are also woodlands. The Petit Clerc forest zone is located near the research station of Ferkessédougou. There are weeds, wood, wild fruits and some mango trees near station. Therefore, it has the same geographical and vegetation coordinates as the said station [10].

\subsection{Animal Materials}

It consisted of fruit flies captured by the traps. Different traps: Tephri-trap, McPhail-trap and local traps were used [3].

\subsection{Plant Materials}

It consisted of the different orchards that served as trapping sites (mango orchard and citrus fruit orchards) and forest zones with their various plant components. 


\subsection{Technical Materials}

\subsubsection{Traps}

Three types of traps were used in this study. They included: (1) Tephri-trap ${ }^{\odot}$ (Sorygar S.L., Quinta del Sol n. 37, Las Rozas, Madrid 28230, España); (2) McPhail-trap (ChemTica Internacional, S.A., Zeta Industrial Park, La Valencia, Heredia, Costa Rica); (3) local traps (plastic bottle). The Tephri-traps and McPhails were made of a yellow-colored box, with five circular holes, four of which were on the top wall and one on the silt-up base, on which a nacelle was fitted.

\subsubsection{Attractants}

Sexuel attractants parapheromones and food attractants served as bait in this study. Sex parapheromones specifically attract male adult flies, while food attractants attract both males and females. Methyl eugenol, trimedlure and cue-lure were the sexuel attractants used. The food attractants used in the design were CeraTrap, torula yeast (high protein) $[11,12]$.

\subsubsection{Insecticide}

DDVP or dichlorvos (phosphate dichloro-2, 2 vinyl and dimethyl) was the only insecticide used to kill the flies.

\subsection{Methodology}

\subsubsection{Preparation of Food Bait (Solution)}

Torula yeast is in solid form. It was obtained through a process of aerobic fermentation, using distiller's vinasse as substrate. It was from the industrial complex "Antonio Sánchez" in the Cienfuegos province, Cuba [13]. Three blocks of torula were taken and mixed with $3 \mathrm{~g}$ of borax, and then the whole was dissolved in $250 \mathrm{~mL}$ of water. The slurry obtained was used for trapping. CeraTrap is in the form of a solution in $5 \mathrm{~L}$ water bottle, and $250 \mathrm{~mL}$ of this solution was collected for fruit fly trapping.

\subsubsection{Setting Up of Traps}

The traps were suspended from a primary branch of the lower third of the foliage, at an average height of
1.5-1.8 $\mathrm{m}$ above ground and sheltered from sunlight.

The branch supporting the trap was previously coated with solid grease in order to prevent any predatory activity of ants against dead adult flies waiting in the trap. On each site, five traps, including three Tephri-traps, one McPhail-traps and one local trap were placed in line with a minimum distance of $40 \mathrm{~m}$. The system was repeated three times, that is, a total of 15 traps/site with the exception of the citrus fruit orchard, which had only five traps to know if the citrus orchard is a refuge area for fruit flies. The traps worked thanks to the attractants that attracted the target insects and the insecticide that killed the insects which came into the traps enabling to recover them during trap checks. The Tephri-traps were baited with methyl eugenol, trimedlure and cue-lure sex attractants to allow for fluctuations of male flies. These attractants were renewed every month. The McPhail-traps were baited with food attractants (two with torula yeast and one with CeraTrap), to allow for monitoring the dynamics of fly population.

\subsubsection{Trap Checking}

The traps were checked every week in the morning. The captured flies were collected, counted, washed and then stored in $70^{\circ}$ alcohol-containing pillboxes. The pillboxes had a double labeling, one inside and the other one outside. The checking date, site name, trap number, type of attractant in the trap, name of collector, number of flies in the trap, as well as the phenological stage of the tree carrying the trap were written on each label in pencil (indelible in alcohol). Sex attractants and insecticide strips were renewed monthly in order to maintain their attractive and insecticidal effects [14, 15]. Food attractants: CeraTrap was renewed every two months, torula dissolved in water was renewed every month. The insects were transported to the laboratory for identification.

\subsubsection{Identification of Captured Flies}

The flies captured in the different traps were identified using binocular lens, by observing the 


\section{Assessment of Fruit Fly Trapping System in Mango Orchards in Northern Côte d'Ivoire}

morphological characters. Identification plates and guides (key) with the specific characteristics of the different flies were used for this purpose [16-18].

\subsubsection{Data Analysis}

The relative abundance of trapped flies and the average capture of fruit flies per attractant were subjected to analysis of variance (ANOVA) at 5\% threshold. The ANOVA was followed in case of significant difference, by an average comparison test (Student's test). Before performing the ANOVA, a verification of the normality of data distribution was carried out using the Shapiro-Wilk test (Shapiro \& Wilk, 1965). In case of abnormal distribution, data transformations were carried out according to the arc-sine square root of $X$ formula so as to correct their normality. All statistical tests were carried out using the STATISTICA 7.1 software (Statistica v. 7.1).

\section{Results}

\subsection{Inventory of Fruit Fly Species}

An inventory of 10 species of fruit flies belonging to the genus Bactrocera spp., Ceratitis spp. and Dacus spp. was made on all the study sites. These included: B. cucurbitae, B. dorsalis, C. anonae, C. bremii, C. capitata, C. cosyra (Walker), C. punctata, D. ciliatus, D. punctatifrons and Dacus spp.. The genus Ceratitis showed the highest specific richness with five species identified (56\% of the diversity) against two for the genus Dacus (22\%) and two for the genus Bactrocera (22\%). Of the 10 species listed, eight were commonly encountered on all sites and two were found in two sites and three of the four study sites. B. dorsalis was predominantly represented on all trapping sites. It was captured by $94.04 \%$ in mango tree orchards on stations and by $90.94 \%$ in forest zone. Its average capture was $292.45 \pm 47.82,261.92 \pm 56.36,219.05 \pm$ 42.3 and $175.89 \pm 42.09$ individuals, respectively, at the station of Lataha, Diabaté Kamonon, Ferké and Petit Clerc. The other species were minority and the average captures fluctuated from $5.8 \pm 3.57$ individuals to $11.21 \pm 4.31$ individuals at the station of
Lataha, from $5.56 \pm 1.54$ individuals to $21.94 \pm 14.33$ individuals at Diabaté Kamonon, from 2.0 individuals to $64.98 \pm 12.45$ individuals at the station of Ferké and from 1.0 individual to $13.35 \pm 5.57$ individuals at Petit Clerc (Table 1). Among these minority species, $B$. cucurbitae was the most represented with $34.5 \pm 6.5$ individuals in Lataha. At Diabaté Kamonon and at the station of Ferké, C. punctata and C. cosyra with an average capture of $35.88 \pm 11.15$ individuals and $64.98 \pm 12.45$ individuals were the most abundant, respectively. Finally, C. bremii with $13.35 \pm 5.57$ individuals on average was the most captured after $B$. dorsalis at Petit Clerc. The weakly represented $D$. ciliatus species was captured only at the station of Ferké (Table 1). The overall analysis of the results showed a diversity of the genus Ceratitis on the trapping sites. However, the Shannon-Weaver index estimated at $0.52,0.37,0.38$ and 0.21 and the Piélou index estimated at $0.1,0.25,0.16$ and 0.19 , respectively at Diabaté Kamonon, station of Ferké, Petit Clerc and station of Lataha, revealed a low species richness of the environments and an unequal distribution of the species of flies in the environments. Statistical treatments revealed a highly significant difference $(p<0.01)$ between the relative abundance of fruit flies per site. Concerning the other orchards (refuge zones) in Lataha, the finding was the same and the species of flies identified were identical to those of the first four sites. A strong representation of $B$. dorsalis compared to other species was also observed. Its average capture was estimated to be $79.02 \pm 30.3$, $30.87 \pm 8.62$ and $117.24 \pm 32.53$ individuals, respectively, in orchards of citrus fruit, cashew nuts and mixed plots (papaya and banana combination) (Table 2).

\subsection{Spatio-Temporal Fluctuation of Fruit Fly Populations on Trapping Sites}

Overall, the fruit fly population persisted throughout the year on trapping sites. At the station of Lataha, started from 5,000 flies in May 2015, the population 
Table 1 Average capture of fruit flies per trapping site.

\begin{tabular}{lllll}
\hline Species & Station of Lataha & Diabaté Kamonon forest & Station of Ferké & Petit Clerc forest \\
\hline B. dorsalis & $292.45 \pm 47.82^{\mathrm{b}}$ & $261.92 \pm 56.36^{\mathrm{b}}$ & $219.05 \pm 42.30^{\mathrm{b}}$ & $175.89 \pm 42.09^{\mathrm{b}}$ \\
C. bremii & $11.21 \pm 4.31^{\mathrm{a}}$ & $9.80 \pm 2.01^{\mathrm{a}}$ & $5.13 \pm 0.86^{\mathrm{a}}$ & $13.35 \pm 5.57^{\mathrm{a}}$ \\
C. cosyra & $9.75 \pm 1.90^{\mathrm{a}}$ & $21.94 \pm 14.33^{\mathrm{a}}$ & $64.98 \pm 12.45^{\mathrm{a}}$ & $6.75 \pm 0.99^{\mathrm{a}}$ \\
C. capitata & $3.32 \pm 0.70^{\mathrm{a}}$ & $6.80 \pm 2.49^{\mathrm{a}}$ & $2.10 \pm 0.78^{\mathrm{a}}$ & $6.45 \pm 1.83^{\mathrm{a}}$ \\
C. punctata & $3.13 \pm 0.94^{\mathrm{a}}$ & $35.88 \pm 11.15^{\mathrm{a}}$ & $15.04 \pm 3.14^{\mathrm{a}}$ & $11.00 \pm 2.91^{\mathrm{a}}$ \\
C. anonae & $2.63 \pm 0.31^{\mathrm{a}}$ & $5.56 \pm 1.54^{\mathrm{a}}$ & $3.63 \pm 1.39^{\mathrm{a}}$ & $6.30 \pm 1.37^{\mathrm{a}}$ \\
B. cucurbitae & $34.50 \pm 6.50^{\mathrm{a}}$ & - & $2.00 \pm 0.00^{\mathrm{a}}$ & - \\
Dacus spp. & $13.10 \pm 1.63^{\mathrm{a}}$ & $21.94 \pm 3.70^{\mathrm{a}}$ & $10.37 \pm 1.45^{\mathrm{a}}$ & $12.89 \pm 2.20^{\mathrm{a}}$ \\
D. punctatifrons & $5.80 \pm 3.57^{\mathrm{a}}$ & $6.67 \pm 2.69^{\mathrm{a}}$ & $5.67 \pm 4.67^{\mathrm{a}}$ & $1.00 \pm 0.00^{\mathrm{a}}$ \\
D. ciliatus & - & - & $5.00 \pm 0.00^{\mathrm{a}}$ & - \\
Probability $(p)$ & $p=0.000005$ & $p=0.00002$ & $p=0.0048$ & $p=0.0090$ \\
\hline - Absence & & & &
\end{tabular}

-: Absence of species.

ANOVA at $5 \%$ threshold. The averages assigned with the same letter in the column are not significantly different.

Table 2 Average capture of fruit flies in refuge zones.

\begin{tabular}{llll}
\hline Species & Citrus fruit orchard & Cashew tree orchard & Papaya and Banana combination \\
\hline B. dorsalis & $79.02 \pm 30.30^{\mathrm{a}}$ & $30.87 \pm 8.62^{\mathrm{a}}$ & $117.24 \pm 32.53^{\mathrm{a}}$ \\
C. cosyra & $13.40 \pm 3.36^{\mathrm{a}}$ & $4.89 \pm 1.14^{\mathrm{a}}$ & $7.54 \pm 2.06^{\mathrm{a}}$ \\
C. anonae & $10.33 \pm 3.09^{\mathrm{a}}$ & $4.67 \pm 1.74^{\mathrm{a}}$ & $1.75 \pm 0.75^{\mathrm{a}}$ \\
C. bremii & $1.00 \pm 0.00^{\mathrm{a}}$ & $1.20 \pm 0.20^{\mathrm{a}}$ & $6.33 \pm 0.56^{\mathrm{a}}$ \\
C. capitata & $2.00 \pm 0.00^{\mathrm{a}}$ & $2.00 \pm 0.00^{\mathrm{a}}$ & $2.83 \pm 1.28^{\mathrm{a}}$ \\
C. ditissima & $1.00 \pm 0.00^{\mathrm{a}}$ & $1.00 \pm 0.00^{\mathrm{a}}$ & $5.50 \pm 4.50^{\mathrm{a}}$ \\
Dacus spp. & $4.91 \pm 1.21^{\mathrm{a}}$ & $11.41 \pm 2.26^{\mathrm{a}}$ & $19.06 \pm 3.94^{\mathrm{a}}$ \\
D. punctatifrons & $1.50 \pm 0.50^{\mathrm{a}}$ & - & $7.80 \pm 2.89^{\mathrm{a}}$ \\
D. bivittatus & - & - & $1.00 \pm 0.00^{\mathrm{a}}$ \\
B. cucurbitae & $1.00 \pm 0.00^{\mathrm{a}}$ & - & $8.33 \pm 4.48^{\mathrm{a}}$ \\
Probability $(p)$ & $p=0.73$ & $p=0.4$ & $p=0.2$ \\
\hline
\end{tabular}

-: Absence of species.

ANOVA at $5 \%$ threshold. The averages assigned with the same letter in the column are not significantly different.

of flies rapidly grew to reach a peak (12,215 flies) in June, then a second peak (15,000 flies) in August before falling down to 357 flies in January. After this period, the population gradually resumed its growth (Fig. 1). The variation of the fruit fly population at the station of Ferké was similar (same pace) to that of the forests of Diabaté Kamonon and Petit Clerc. At Diabate Kamonon, the peak growth of the population of flies was observed in July 2015 with 17,119 individuals before falling down to 22 individuals in April and then resuming its growth from May. At the station of Ferké, the peak of the population was observed in June (17,000 individuals), and then declined rapidly in March before resuming its growth (Fig. 1). At the Petit Clerc forest zone, the peak of flies (12,215 individuals) was also observed in June 2015. The population declined sharply to two individuals in April before resuming its growth (Fig. 1).

\subsection{Spatio-Temporal Fluctuation of B. dorsalis on Trapping Sites}

Due to its large invasion, the variation in B. dorsalis population reflects the pattern of fly population dynamics on each trapping site. At the station of Lataha, growth peaks of this species were observed in June and August 2015 with 11,965 individuals and 14,532 individuals, respectively, then declined before resuming its growth. At the station of Ferké and Petit Clerc, peaks of $B$. dorsalis populations were observed in June 2015, and July 2015 in the Diabaté Kamonon 


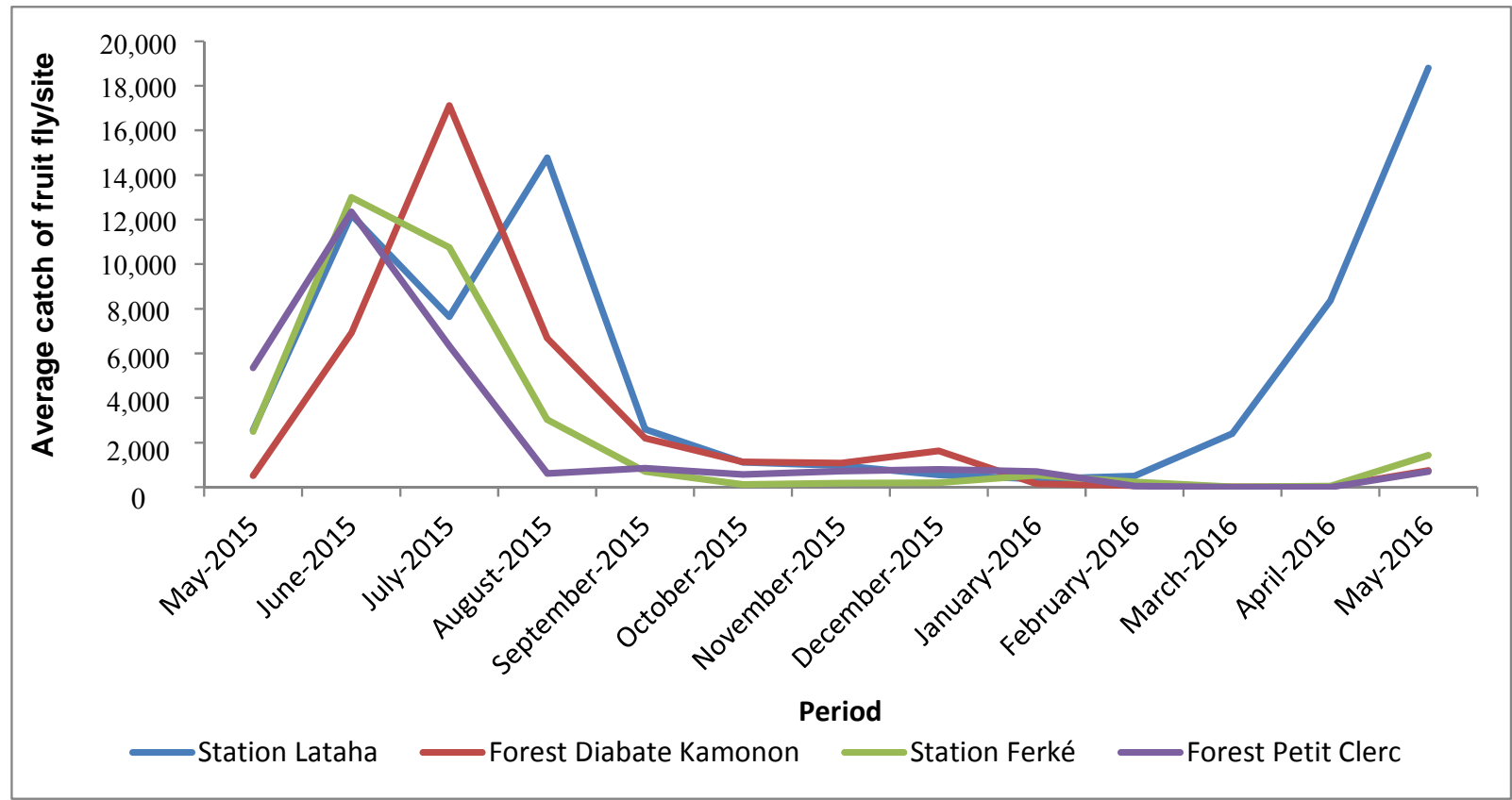

Fig. 1 Dynamics of fruit fly populations on the different trapping sites.

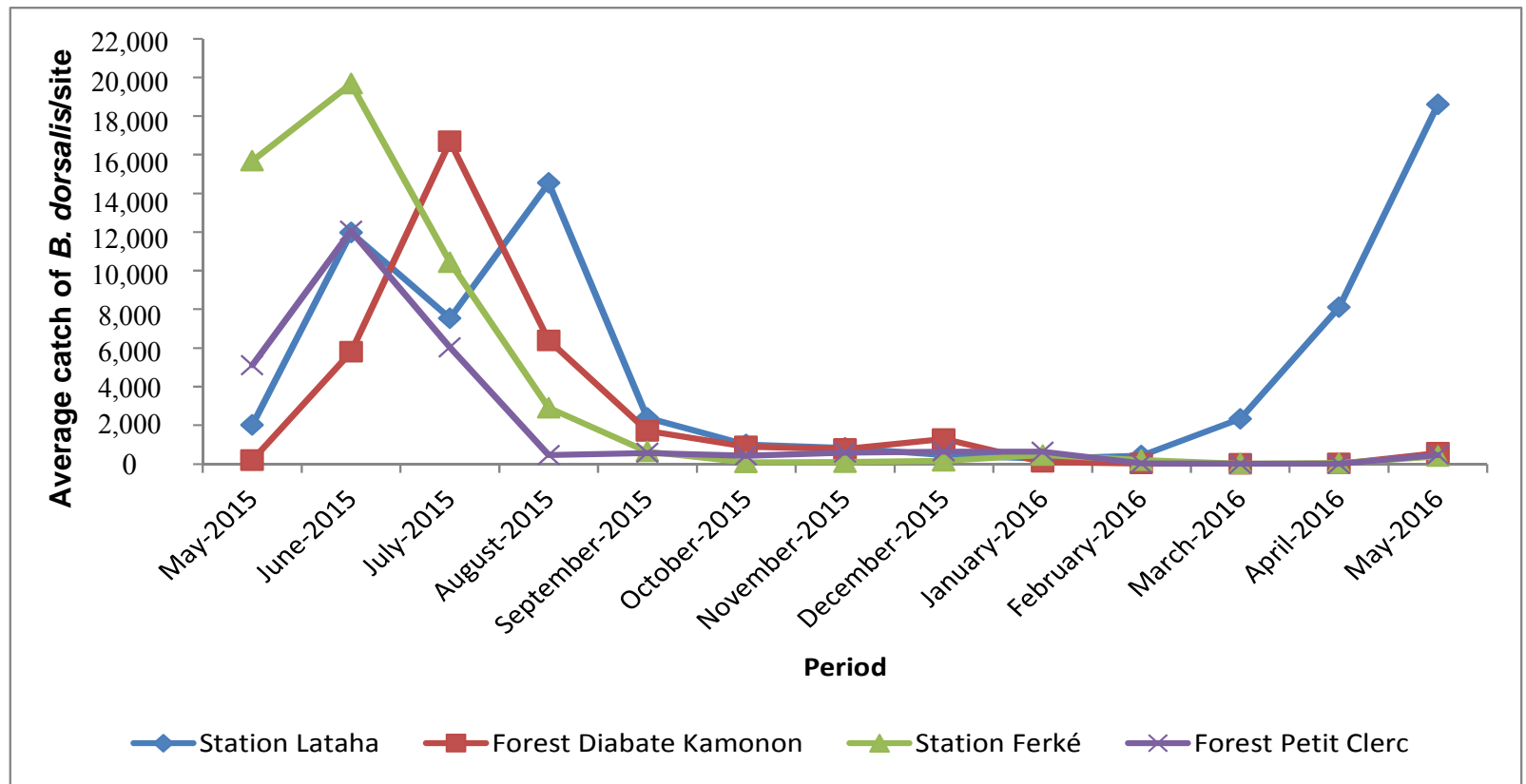

Fig. 2 Dynamics of $B$. dorsalis populations on the different trapping sites.

forest area before resuming its growth as from April (Fig. 2).

\subsection{Efficiency of Attractants}

The capture rate of fruit flies per attractant (sex attractants and food attractants) varied from one bait to another. This rate ranged from $1.57 \%$ to $86.82 \%$ depending on the attractants. The highest capture rate was observed with methyl eugenol achieving $86.82 \%$ of captures. The capture rates of the other attractants were estimated at $5.00 \%, 3.40 \%, 3.13 \%$ and $1.57 \%$, respectively, for torula, CeraTrap, cue-lure and trimedlure (Fig. 3). The same holds for the average capture of fruit flies per attractant on trapping sites. The 


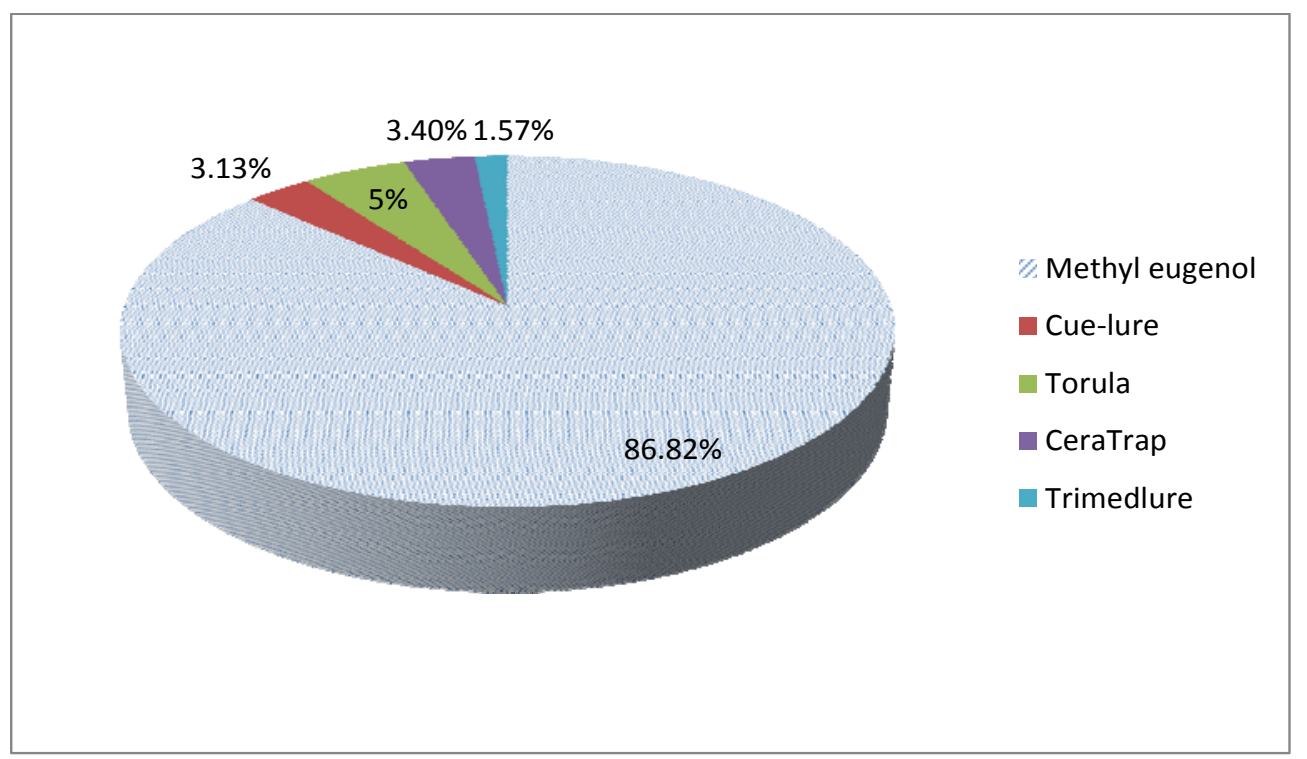

Fig. 3 Proportion of fruit flies captured per attractant.

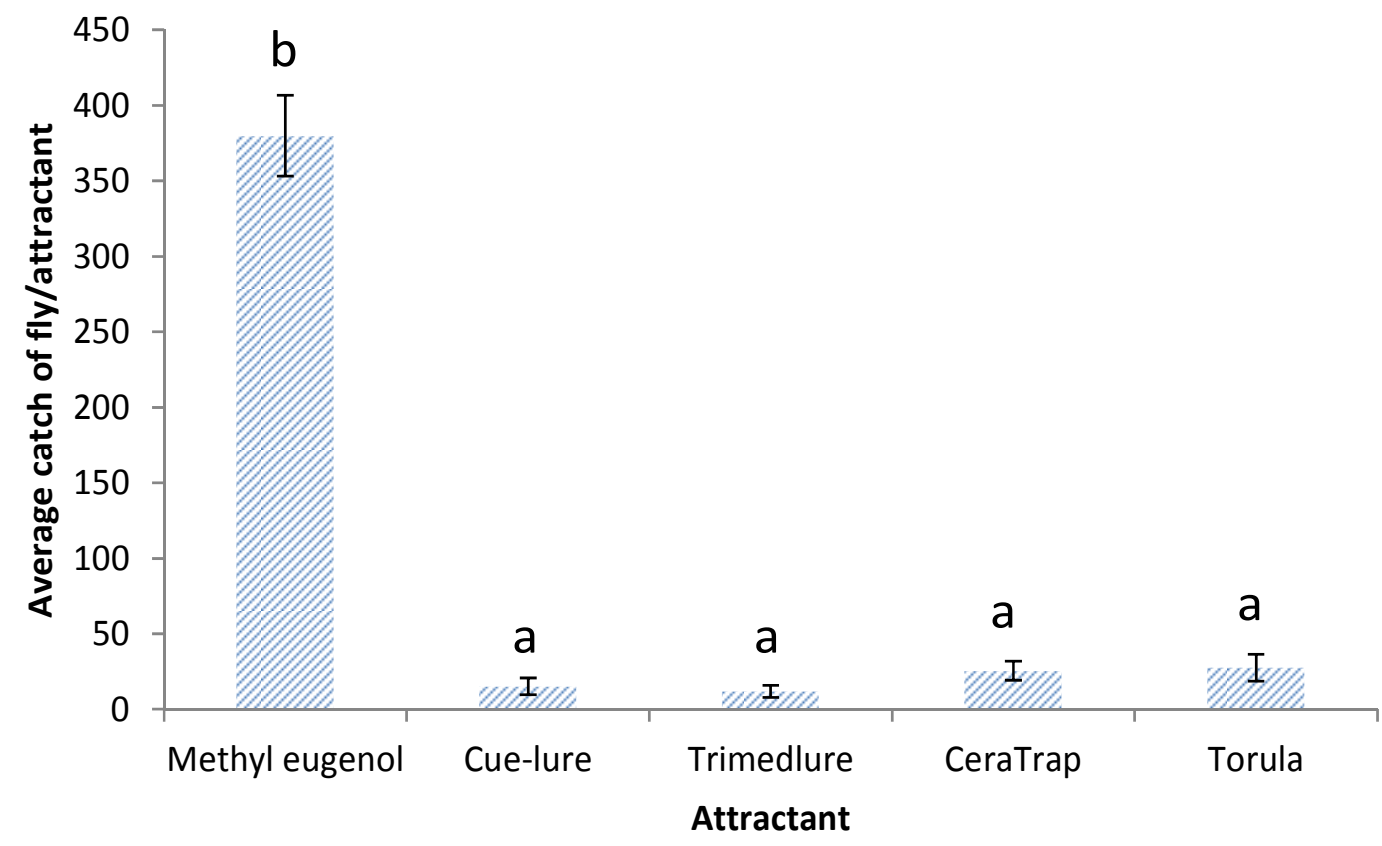

Fig. 4 Average capture of fruit flies per attractant on the sites.

ANOVA at $5 \%$ threshold. The averages assigned with the same letter in the column are not significantly different. Degree of freedom $=5$; homogeneity test of the variances $(F)=52.56$; probability $(p)=0.0000$.

highest average capture was achieved by methyl eugenol with $380 \pm 26.00$ individuals/capture. Concerning other attractants, captures were relatively low compared to that of methyl eugenol. Among the latter, Torula stood out with an average capture of 28 \pm 8.00 individuals (Fig. 4). The statistical treatments revealed a highly significant difference $(p<0.01)$ between the efficiency of traps (attractants).

\section{Discussion}

A total of 10 fruit fly species were collected at the trapping sites. Most of these fruit fly species had been 
identified to Tanzania, Benin and Mali [19-21] and in Côte d'Ivoire [14, 22-24]. B. dorsalis was predominantly represented in the north of the country, the main export mango producing area and has supplanted other species of flies. This could be explained on the one hand by the fact that mango might be a privileged host for this pest. Indeed, this fruit is so prized by the species that it has pledged itself thereto and on the other hand, by intense interspecific competition between this invasive fly and the other indigenous species. Because $B$. dorsalis has progressively adapted to the host plants, with which most endogenous species are associated [8]. It is important to emphasize the absence of certain species depending on the different sites. Indeed, each species has its own period of appearance according to the fruiting periods of host plants. But this absence might also be linked to the strong invasion of ecological niches by $B$. dorsalis, following a large outbreak, to the aggressive behavior of the adults of this species and to the possessive nature, which might be at the origin of a displacement of indigenous species to other ecological niches [25-27]. In contrast, the presence of B. cucurbitae and D. ciliatus at the station of Ferké and Lataha could be explained by the cultivation of Cucurbitaceae in the vicinity, one of the main food crops of the northern zone of the country. Indeed, Vayssière et al. [28], in their research works, emphasize the vassal nature of these two species to Cucurbitaceae.

The monitoring of fruit fly population dynamics, especially the most captured ones on station (mango orchards) and in forest areas, revealed an abundance of $B$. dorsalis on the different sites. In mango orchards, B. dorsalis had a large population during the mango season, coinciding with the rainy season in the northern part of the country. This could explain the large growth peaks observed in June and August at the stations of Lataha and Ferké. The considerable decrease in B. dorsalis population from September onwards might de due to the rarity or even the absence of mango on these sites. Duyck et al. [8], in his research works, indicates the low population level of this invasive species as from September, period coinciding with the dry season and during which occurs mango tree flowering and fruit setting. In the forest zones, peaks of populations were observed in June for the Petit Clerc area and in July for the Diabate Kamonon area. These important peaks of $B$. dorsalis populations could be explained by the fruiting of host plants, in addition to a few mango orchards in the vicinity of these sites. Thus, this might be due to its super competitor nature, in addition to high fertilization, high fertility and a short development cycle compared to endogenous species [26, 29-31]. Among the different trapping systems (trap-attractant complex), methyl eugenol was very impressive in the capture of $B$. dorsalis. This attractant has captured more than any other attractant. Besides this species, other B. cucurbitae fly species have been captured by the same attractant although minority. Therefore, methyl eugenol proved to be effective in monitoring fruit flies.

\section{Conclusions}

Fruit flies persist throughout the year, but their population level varies according to the seasons of the year. This level is important in rainy season and mango season. Exotic fly B. dorsalis is the dominant species and has invaded the entire mango producing area. It has also adapted to a large range of host plants, so much so that it has supplanted endogenous species. The attractants have shown their specificity in capturing fly species. Methyl eugenol had the highest capture and was the most effective. The reason for capturing fruit flies is to detect their presence in orchards and alert mango producers when the fly population increases for integrated pest management.

From these results, targeted recommendations can be made for the detection and trapping of fruit flies. 


\section{Acknowledgments}

The authors would like to extend their warmest thanks to the Economic Community of West African States (ECOWAS), the West and Central African Council for Agricultural Research and Development (CORAF/WECARD) and all associated partners for initiating and implementing the project "Support Project for the Regional Plan for the Fight and Control of Fruit Flies in West Africa" and for involving them. The authors would also like to thank the Developing African-European Joint Collaboration for Science and Technology (ERAFRICA), the Royal Museum of Central Africa (RMCA) and the International Agency of Energy Atomic (IAEA) (through project RAF5061) for their contribution to carrying out the research activities.

\section{References}

[1] Bárbara, R., Mora, L., Oliveira, M. D., Euler, A. C., Larav, L., and Lezcano, P. 2011. "Chemical Composition and Nutritive Value of Torula Yeast (Candida utilis), Grown on Distiller's Vinasse, for Poultry Feeding." Cuban Journal of Agricultural Science 45 (3): 261-5.

[2] The Europe-Africa-Caribbean-Pacific Liaison Committee (COLEACP). 2007. Preliminary Activity Report on Fruit Flies in West Africa: Involvement of COLEACP/PIP. (in French)

[3] Pierre, D. J., Quilici, S., Ratnadass, A., Ryckewart, P., and Vayssières, J. F. 2015. "Fruit Flies (Diptera: Tephritidae) Identified in the Southern Part of Haiti." Faunistic Entomology 68: 193-200. (in French)

[4] De Meyer, M. 1996. "Revision of the Subgenus Ceratitis (Pardalaspis) Bezzi, 1918 (Diptera: Tephritidae, Ceratitini)." Sytematic Entomology 21 (1): 15-26.

[5] De Meyer, M. 1998. "Revision of the Subgenus Ceratitis (Ceratalaspis) Hancock (Diptera: Tephritidae).” Bulletin of Entomological Research 88: 257-90.

[6] De Meyer, M. 2000. "Systematic Revision of the Subgenus Ceratitis MacLeay s.s. (Diptera: Tephritidae)." Zoological Journal of Linnean Society 128 (4): 439-67.

[7] Duyck, P. F., David, P., Junod, G., Brunel, C., Dupont, R., and Quilici, S. 2006. "Importance of Competition Mechanisms in Successive Invasions by Polyphagous Tephritids in La Réunion.” Ecology 87 (7): 1770-80.

[8] Duyck, P. F., David, P., and Quilici, S. 2007. "Can More K-Selected Species Be Better Invader? A Case Study of Fruit Flies in La Réunion.” Diversity and Distrbitions 13
(5): 535-43.

[9] Ekesi, S., Billah, M. K., Nderitu, P. W., Lux, A. S., and Ivan, R. 2009. "Evidence for Competitive Displacement of Ceratitis cosyra by the Invasive Fruit Fly Bactrocera invadens (Diptera: Tephritidae) on Mango and Mechanisms Contribution to the Displacement.” Journal of Economic Entomology 102 (3): 981-91.

[10] Hala, N. F. 2001. Fruit Fly Control. CNRA/ICIPE Convention, Technical Implementation Report 2000, CNRA, 11. (in French)

[11] Hala, N. F., Quilici, S., Gnago, A. J., N’Dépo, O. R., Kouassi, K. P., and Allou, K. R. 2006. "Status of Fruit Flies (Diptera: Tephritidae) in Côte-d'Ivoire and Implications for Mango Exports." In Proceeding of 7th International Symposium on Fruit Flies of Economic Importance, Salvadore, Bahia, Brazil, 233-9.

[12] Jean-Philippe, D. 2013. "Agronomic and Socio-Economic Approaches for the Design of Ecologically Innovative and Economically Efficient Horticultural Systems: Innovative Vegetable Cropping Systems in Reunion." International Journal of Agricultural Sustainability 3: 11-4.

[13] Lasm, T., Fossou, N. R. M., Onetie, Z. O., Baka, D., Youan, T. M., Oga, M. S., and Soro, N. 2012. "Hydrogeological Contribution to the Knowledge of Discontinuous Aquifers in the Department of Ferké (Northern Côte d'Ivoire) for a Better Supply of Drinking Water." Ivorian Journal of Science and Technology 19: 114-35. (in French)

[14] Vayssières, J. F., Sinzogan, A., Korie, S., Ouagoussounon, I., and Odjo, A. T. 2009. "Effectiveness of Spinosad Bait Sprays (GF-120) in Controlling Mango-Infesting Fruit Flies (Diptera: Tephritidae) in Benin." Journal of Economic Entomology 102 (2): 515-21.

[15] Mwatawala, M. W., De Meyer, M., Makundi, R. H., and Maerere, A. P. 2009. "An Overview of Bactrocera (Diptera: Tephritidae) Invasive and Their Speculated Dominancy over Native Fruit Fly Species in Tanzania." Academic Journal of Entomology 6 (1): 18-27.

[16] Mwatawala, M. W., De Meyer, M., Makundi, R. H., and Maerere, A. P. 2009. "Host Range and Distribution of Fruit-Infesting Pestiferous Fruit Flies (Diptera: Tephritidae) in Selected Areas of Central Tanzania." Bulletin of Entomological Research 99 (6): 629-41.

[17] Mwatawala, M. W., White, I. M., Maerere, P. A., Sekondo, F. J., and De Meyer, M. 2004. "A New Invasive Bactrocera Species (Diptera: Tephritidae) in Tanzania." African Entomology 12 (1): 154-6.

[18] Norrbom, A. 2004. The Diptera Site. Fruit Fly (Diptera: Tephtitidae) Classification and Diversity. Systematic and Entomology Laboratory, ARS, USDA.

[19] N'Dépo, O. R. 2006. "Inventory of Fruit Flies (Diptera: 

in Northern Côte d'Ivoire

Tephritidae) at Experimental Stations in Azaguié and Yamoussoukro (Côte d'Ivoire).” D.E.A thesis in General Entomology, University of Cocody Abidjan (RCI), 59. (in French)

[20] N'Dépo, O. R. 2010. "Biology and Ecology of Bactrocera invadens Drew, Tsuruta and White, 2005 (Diptera: Tephritidae), Main Predator of Fruit Orchards in Côte d'Ivoire: Possibility of Reasoned Chemical Control against Fruit Flies.” Ph.D. thesis, the University of Cocody, 177. (in French)

[21] N'Dépo, O. R., Hala, N. F., Allou, K., Aboua, L. R., Kouassi, K. P., Vayssières, J. F., and De Meyer, M. 2009. "Abundance of Fruit Flies in Fruit Producing Areas of Ivory Coast: Population Dynamics of Bactrocera invadens (Diptera: Tephritidae)." Fruits 64 (5): 313-24.

[22] N'Dépo, O. R., Hala, N. F., Gnago, A., Allou, K., Kouassi, K. P., Vayssières, J. F., and De Meyer, M. 2010. "Inventory of Fruit Flies from Three Agroecological Regions and Host Plants Associated with the New Species Bactrocera (Bactrocera) invadens (Diptera: Tephritidae) in Côte d'Ivoire." European Journal of Scientific Research 46 (1): 63-72. (in French)

[23] N'Guetta, K. 1994. "Inventory of Insects of Fruits Harvested in Northern Côte d'Ivoire." Fruits 49: 502-3. (in French)

[24] N'Guetta, K. 1995. "Inventory of Insect Fruit Pest in Northern Côte d'Ivoire.” Fruits 49: 430-1.

[25] Raghu, S. 2002. "The Autecologie of Bactrocera cacuminata (Hering) (Diptera: Tephritidae: Dacinae):
Functional Significance of Resources." Ph.D. thesis, Griffith University, Griffith, Australia, 241.

[26] Ouédraogo, S. N., Vayssières, J. F., Dabiré, A. R., and Rouland-Lefèvre, C. 2011. "Biodiversity of Fruit Flies (Diptera: Tephritidae) in Mango Orchards in Western Burkina Faso: Comparison of Structure and Communities of Different Sites." Fruits 66: 393-404.

[27] Vannière, H., Christian, D., Rey, J. Y., Thierno, M. D., Sidiki, K., and Morodjan, S. 2004. "Mango in French-Speaking West Africa: Production Systems and Technical Itineraries." Fruits 59 (6): 383-98. (in French)

[28] Vayssière, J. F., Fatogoma, S., and Moussa, N. 2004. "Inventory of Fruit Fly Species (Diptera: Tephritidae) Specific to Mango Tree in Mali and Reasoned Control Trial." Fruits 59 (1): 1-14. (in French)

[29] Vayssières, J. F., Georg, G., Orphée, L., Dossa, P., and Akponon, C. 2005. "A New Bactrocera Species in Benin among Fruit Fly (Diptera: Tephritidae) Species.” Fruits 60 (6): 371-7.

[30] Vayssières, J. F., Korie, S., and Ayegnon, D. 2009. "Correlation of Fruit Fly (Diptera: Tephritidae) Infestation of Major Mango Cultivars in Borgou (Benin) with Abiotic and Biotic Factors and Assessment of Damage." Crop Protection 28: 477-88.

[31] Vayssières, J. F., Korie, S., Coulibaly, O., Temple, L., and Boueyi, S. P. 2008. "The Mango Tree in Central and Northern Benin: Cultivar Inventory, Yield Assessment, Infested Stages and Loss Due to fruit Flies (Diptera: Tephritidae)." Fruits 63 (6): 335-48. 